This article was downloaded by: [National Astronomical Observatories]

On: 16 January 2013, At: 06:20

Publisher: Taylor \& Francis

Informa Ltd Registered in England and Wales Registered Number: 1072954 Registered office: Mortimer House, 37-41 Mortimer Street, London W1T 3J H, UK

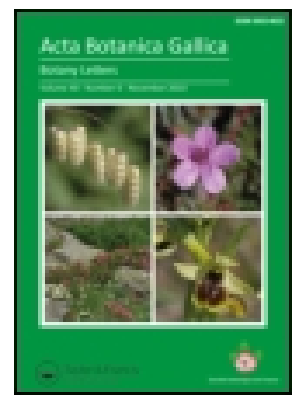

Acta Botanica Gallica
Publication details, including instructions for authors and subscription information:
http://www.tandfonline.com/loi/tabg20

\title{
Floristic and dendrometric analysis of woodlands in the Sudano-Guinean zone: a case study of Belléfoungou forest reserve in Benin
}

\author{
G. Houéto $^{a}$, B. Fandohan ${ }^{\text {a }}{ }^{\text {, }}$, A. Ouédraogo ${ }^{c}$, E.E. Ago ${ }^{\text {d }}$, V.K. Salako ${ }^{a}$, A.E. \\ Assogbadjo ${ }^{a}$, R. Glèlè Kakaï ${ }^{a} \& B$. Sinsin ${ }^{a}$ \\ ${ }^{a}$ Laboratoire d'écologie appliquée, Faculté des sciences agronomiques, Université \\ d'Abomey-Calavi, 01 BP 526, Cotonou, Bénin \\ ${ }^{b}$ International Ecosystem Management Partnership (IEMP), United Nations Environment \\ Programme, c/ o Institute of Geography and Natural Resources Research, Chinese \\ Academy of Sciences, No. 11A Datun Road, Beijing, 100101, China \\ ${ }^{c}$ Laboratoire de biologie et écologie végétales, UFR sciences de la vie et de la terre, \\ Université de Ouagadougou, 03 PB 7021 Ouagadougou, Burkina, Faso \\ ${ }^{\mathrm{d}}$ Unit of Biosystem Physics, Gembloux Agro-Bio Tech, University of Liege, 2 Passage des \\ Déportés, 5030, Gembloux, Belgium \\ Version of record first published: $16 \mathrm{~J}$ an 2013.
}

To cite this article: G. Houéto , B. Fandohan , A. Ouédraogo, E.E. Ago , V.K. Salako, A. E. Assogbadjo, R. Glèlè Kakaï $\&$ B. Sinsin (2013): Floristic and dendrometric analysis of woodlands in the Sudano-Guinean zone: a case study of Belléfoungou forest reserve in Benin, Acta Botanica Gallica, DOI: 10.1080/ 12538078.2012.735124

To link to this article: http:// dx.doi. org/ 10.1080/ 12538078.2012.735124

\section{PLEASE SCROLL DOWN FOR ARTICLE}

Full terms and conditions of use: http://www.tandfonline.com/page/terms-and-conditions

This article may be used for research, teaching, and private study purposes. Any substantial or systematic reproduction, redistribution, reselling, loan, sub-licensing, systematic supply, or distribution in any form to anyone is expressly forbidden.

The publisher does not give any warranty express or implied or make any representation that the contents will be complete or accurate or up to date. The accuracy of any instructions, formulae, and drug doses should be independently verified with primary sources. The publisher shall not be liable for any loss, actions, claims, proceedings, demand, or costs or damages whatsoever or howsoever caused arising directly or indirectly in connection with or arising out of the use of this material. 


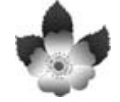

Société botanique de France

\title{
Floristic and dendrometric analysis of woodlands in the Sudano-Guinean zone: a case study of Belléfoungou forest reserve in Benin
}

\section{Analyse floristique et dendrométrique de formations boisées dans la zone soudano-guinéenne: l'exemple de la réserve de la forêt de Belléfoungou au Bénin}

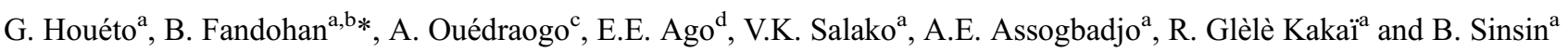 \\ ${ }^{a}$ Laboratoire d'écologie appliquée, Faculté des sciences agronomiques, Université d'Abomey-Calavi, 01 BP 526, Cotonou, Bénin; \\ ${ }^{b}$ International Ecosystem Management Partnership (IEMP), United Nations Environment Programme, c/o Institute of Geography and \\ Natural Resources Research, Chinese Academy of Sciences, No. 11A Datun Road, Beijing, 100101, China; 'Laboratoire de biologie \\ et écologie végétales, UFR sciences de la vie et de la terre, Université de Ouagadougou, 03 PB 7021 Ouagadougou, Burkina, Faso; \\ ${ }^{d}$ Unit of Biosystem Physics, Gembloux Agro-Bio Tech, University of Liege, 2 Passage des Déportés, 5030, Gembloux, Belgium
}

\begin{abstract}
A floristic and dendrometric analysis was carried out using 15 square plots of 1 ha each in the Belléfoungou forest reserve, located in the Sudano-Guinean zone of Benin. Species and diameter at breast height of trees were recorded. Multidimensional scaling and importance value index of species were used to identify vegetation types in the reserve: (1) Isoberlinia tomentosa-dominated vegetation type, (2) Isoberlinia doka and Burkea africana-dominated vegetation type and (3) Vitellaria paradoxa and Isoberlinia doka-dominated vegetation type. Significant differences were noted between the three vegetation types with respect to the basal area of trees. This varied from $8.55 \mathrm{~m}^{2} /$ ha (vegetation type 3) to $13.36 \mathrm{~m}^{2} /$ ha (vegetation type 2). The overall woody species richness was 57 species. The stem diameter structures of all three vegetation types showed an inverse " $J$ " shape, suggesting that the study reserve has stable natural vegetation with relatively more young stems than large stems. Setting and implementation of a sustainable management plan, and supervision reinforcement were suggested to enable conservation of the Belléfoungou forest reserve.
\end{abstract}

Keywords: importance value index; stem diameter structure; Sudano-Guinean zone; vegetation types; West Africa

\begin{abstract}
Résumé: Une caractérisation structurelle de la forêt classée de Belléfoungou, située dans la zone soudano-guinéenne du Bénin, a été effectuée en utilisant quinze placeaux carrés de 1ha. Les espèces ont été notées et les dbh des arbres mesurés au cours de l'inventaire. Le positionnement métrique ainsi que la valeur d'importance des espèces ont été utilisés pour identifier trois types de végétations: (1) la végétation à Isoberlinia tomentosa, (2) la végétation à Isoberlinia doka et Burkea africanaet (3) celle dominée par Vitellaria paradoxa et Isoberlinia doka. La surface terrière des arbres varie significativement entre $8,55 \mathrm{~m} 2 /$ ha (type de végétation 3 ) et $13,36 \mathrm{~m} 2 /$ ha (type de végétation 2 ). La richesse spécifique ligneuse globale est de 57 espèces. Les structures en diamètre des trois types de végétations présentent une forme en " $J$ " renversé, suggérant que la forêt étudiée est caractérisée par une végétation naturelle stable avec relativement plus d' arbres de faible diamètre que d'arbres de gros diamètres. L'élaboration et la mise en oeuvre d'un plan d'aménagement, ainsi que le renforcement des surveillances ont été suggérés pour assurer une conservation durable de la forêt classée de Belléfoungou.
\end{abstract}

Mots-clefs: Afrique de l'Ouest; structure en diamètre; types de végétation; valeur d'importance des espèces; zone soudanoguinéenne

\section{Introduction}

The loss and fragmentation of tropical forests are among the greatest threats to the world's biological diversity (Whitmore 1990; Huston 1994; du Toit, Walker, and Campbell 2004; Adomou et al. 2010). In 1992, the Convention on Biological Diversity highlighted that measures must be implemented for the conservation of natural ecosystems, especially for tropical forests, which are widely recognized as ecosystems hosting the highest overall species diversity on earth (Natta 2003).
Tropical woodlands are one of the tropical vegetation types that continue to erode unabated, a fact that calls for ecologists to address the problem directly and place less reliance on indirect interventions (du Toit, Walker, and Campbell 2004). These woodlands provide around $80 \%$ of the energy needs of both urban and rural populations in Africa and are of similar importance on a more localized scale in other areas. They also provide livestock fodder, building poles and many of the daily needs of the rural people living in and around them (World Bank 2001). 
In Africa, woodlands are mostly represented in the Sudanian and Zambeican (miombos) climatic zones (Bellefontaine, Gaston and Petrucci 2000) after White (1983). In Benin (West Africa), more than half of the territory lies in the Sudanian zone (White 1983). Woodlands cover two-thirds of the total area of dense forest in the dry tropical zone of this country (Sokpon et al. 2006), where they are threatened by deforestation, fire and climate change (Pennie 2008). The rapid changes in land use had led to the progressive destruction and fragmentation of woodlands, which provide fertile soils for cultivation. The traditional use of firewood is another important factor that causes the reduction of woodlands in Benin (Adomou 2005). In $1995,93 \%$ of the total fuel energy used in Benin came from firewood and charcoal (World Bank 1998).

It is widely accepted that conservation of terrestrial biodiversity requires nature reserves, which must be protected from unsustainable human activities (Myers et al. 2000). The Belléfoungou forest reserve, with an area of about 1300 ha, was given the status of "reserve" in 1943 (Hékpazo 1996). To date, this reserve has lost $44 \%$ of its original surface (reduced to only $709 \mathrm{ha}$ ), a result of the high pressure it is facing (Adomou 2005). It therefore deserves urgent intervention for the establishment of a sustainable management plan. Understanding conservation targets, including a full description of ecological communities and the species they host, is a prerequisite of conservation action planning and design (The Nature Conservancy 2003). Furthermore, description and analysis of vegetation types through floristic and dendrometic characterization provide means to analyse the relation between vegetation and climate, edaphic, topographic and human factors (Russell-Smith 1991).

The main objectives of this work were to (i) differentiate the observed vegetation types in the Belléfoungou forest reserve and (ii) assess their structural patterns. As no detailed ecological information is available on the forest, it was not possible to set ecological hypotheses. However, assuming that the pattern of species and vegetation types results from localized dispersal events and local demographic stochasticity, (see Hubbell 2001; Hardy and Sonké 2004), it was hypothesized that the Belléfoungou forest reserve shelters different vegetation types. In addition, as the forest has never benefited from any actual conservation action, it was expected that hosted vegetation types would show declining structures.

\section{Material and methods}

\section{Study area}

This study was conducted in the Belléfoungou Forest Reserve (a tropical woodland), which is located in the Sudano-Guinean transition zone referred to as "Sudanian woodland zone with abundant Isoberlinia spp." after White (1983). In Benin, this zone is located between $9^{\circ}$ $46^{\prime} 40^{\prime \prime}$ and $9^{\circ} 49^{\prime} 00^{\prime \prime} \mathrm{N}$ and between $1^{\circ} 42^{\prime} 00^{\prime \prime}$ and $1^{\circ} 45^{\prime}$ $00^{\prime \prime} \mathrm{E}$. The total area of this forest is estimated at 709 ha with native vegetation dominated by species such as Isoberlinia doka, Isoberlinia tomentosa, Anogeissus leiocarpa, Pterocarpus erinaceus, Vitellaria paradoxa, Burkea africana, Prosopis africana, Pericopsis laxiflora, Afzelia africana and Kaempferia aethiopica, following the botanical nomenclature of Lebrun and Stork (19911997). The rainfall regime is unimodal with a mean annual rainfall of $1000-1200 \mathrm{~mm}$. Soils are mainly ferruginous (Adomou 2005).

\section{Forest inventory design and data collection}

A forest inventory was made using a random sampling scheme. Data were collected in 1-ha plots laid out at least $500 \mathrm{~m}$ apart. The floristic homogeneity of the vegetation and the uniformity of ecological properties of the stand were taken into account before plot setting as described by Braun-Blanquet (1972) and Kent and Coker (1992).The inventory scheme consisted of 15 plots representing $2.12 \%$ of the total surface covered by the forest reserve.

In each plot, all trees of diameter at breast height $(\mathrm{dbh})>10 \mathrm{~cm}$ were recorded and their diameter at 1.3 $\mathrm{m}$ above ground was measured. The binomial nomenclature of each tree species was recorded following the botanical nomenclature of Lebrun and Stork (1991-1997) as well as the number of trees per species.

\section{Identification and characterization of vegetation types \\ Identification of vegetation types}

The absolute frequencies of all species recorded within the 15 1-ha plots were grouped in a matrix and then submitted to multidimensional scaling to map the plots according to their species composition. The ALSCAL procedure of SPSS software version 16.0 was used to build a bi-dimensional geometric structure based on the observed similarity or dissimilarity among plots.

\section{Characterization of identified vegetation types}

For the whole reserve and for each identified vegetation type, the following dendrometric parameters were computed:

- tree-density of the stand $(N)$, i.e. the average number of trees per sample plot, expressed as trees per hectare;

- basal area of the stand $(G)$, i.e. the sum of the cross-sectional areas at $1.3 \mathrm{~m}$ above ground level of all trees in a 1-ha plot, expressed as $\left(\mathrm{m}^{2} / \mathrm{ha}\right)$ :

$$
\mathrm{G}=\frac{0.0001 \pi}{4} \sum_{\mathrm{i}=1}^{\mathrm{n}} \mathrm{d}_{\mathrm{i}}^{2}
$$


where $d_{i}$ is the diameter (in $\mathrm{cm}$ ) of the tree $i$ of the plot;

- mean diameter of the tree $\left(D_{g}\right)$, i.e. the diameter of the tree with mean basal area or quadratic mean diameter, expressed in $\mathrm{cm}$ as:

$$
\mathrm{D}_{\mathrm{g}}=\sqrt{\frac{1}{\mathrm{n}} \sum_{\mathrm{i}=1}^{\mathrm{n}} \mathrm{d}_{\mathrm{i}}^{2}}
$$

where $n$ is the number of trees found on the plot and $d_{i}$ is the diameter of the tree $i$ (in $\mathrm{cm}$ ).

Three floristic parameters were considered:

- the species richness ( $S$, in species), i.e. the cumulative number of species recorded in the 15 plots;

- the Shannon diversity index $(H)$, computed using the following formula:

$$
\mathrm{H}=-\sum_{\mathrm{i}=1}^{\mathrm{s}} \frac{\mathrm{n}_{\mathrm{i}}}{\mathrm{n}} \log _{2} \frac{\mathrm{n}_{\mathrm{i}}}{\mathrm{n}}
$$

where $n_{i}$ is the number of trees of species $i, n$ is the overall number of inventoried trees in all the plots and $S$ is the species richness;

- the Pielou evenness index (Eq); this index measures the diversity degree of a stand compared with the possible maximum and is computed for each plot as follows:

$$
\mathrm{E}_{\mathrm{q}}=\frac{\mathrm{H}}{\mathrm{H}_{\max }} \text { with } \mathrm{H}_{\max }=\log _{2} \mathrm{~S}
$$

In Eq (4), $H$ represents the Shannon diversity index, $H_{\max }$ is the maximum value of the diversity index and $S$ is the number of tree-species recorded in the considered plot.
The mean and coefficient of variation of the dendrometric parameters $N, G, D_{g}$ were calculated for the whole reserve and for each identified vegetation type separately; subsequently, an analysis of variance was carried out to compare the vegetation types according to these parameters.

Finally, to analyse the possible shift in species composition of each vegetation type, the importance value index $(I V I)$ of each species was computed (Curtis and Macintosh 1951). For a species $i$, the $I V I_{i}$ was computed using equation (5):

$$
\mathrm{IVI}_{\mathrm{i}}=\mathrm{RD}_{\mathrm{i}}+\mathrm{RF}_{\mathrm{i}}+\mathrm{RC}_{\mathrm{i}}
$$

where $R D_{i}$ is the relative density of species $i$ : $R D_{\mathrm{i}}=\mathrm{Ni} / \Sigma_{\mathrm{i}=1}^{\mathrm{p}} \mathrm{Ni}$,

where $\mathrm{p}$ is the total number of species and $N_{i}$ is the tree-density of the species $i$;

$R F_{i}$ is the relative frequency of the species $i: R F_{\mathrm{i}}=$ $\mathrm{f}_{\mathrm{i}} / \sum_{\mathrm{i}=1}^{\mathrm{p}} \mathrm{f}_{\mathrm{i}}, \mathrm{f}_{\mathrm{i}}=\frac{\mathrm{j}_{\mathrm{i}}}{\mathrm{k}}$,

where $f_{i}$ is the frequency of the species $i, j_{i}$ is the number of plots at which the species $i$ was counted, and $k$ is the total number of plots.

$R C_{i}$ is the relative coverage for the species $i: R C_{\mathrm{i}}=$ $\mathrm{C}_{\mathrm{i}} / \sum_{\mathrm{i}=1}^{\mathrm{p}} \mathrm{C}_{\mathrm{i}}, \mathrm{C}_{\mathrm{i}}=\frac{\mathrm{a}_{\mathrm{i}} \mathrm{N}_{\mathrm{i}}}{\mathrm{n}_{\mathrm{i}}}$

where $C_{i}$ is the coverage of the species $i$, i.e. the proportion of the ground occupied by a vertical projection to the ground from the aerial parts of the plant; $a_{i}$ is the basal area of the species $i ; N_{i}$ is the tree-density of the species $i$ and $n_{i}$ is the total number of individuals sampled for that species.

The IVI-value is referred to as the importance percentage. It gives an overall estimation of the level of

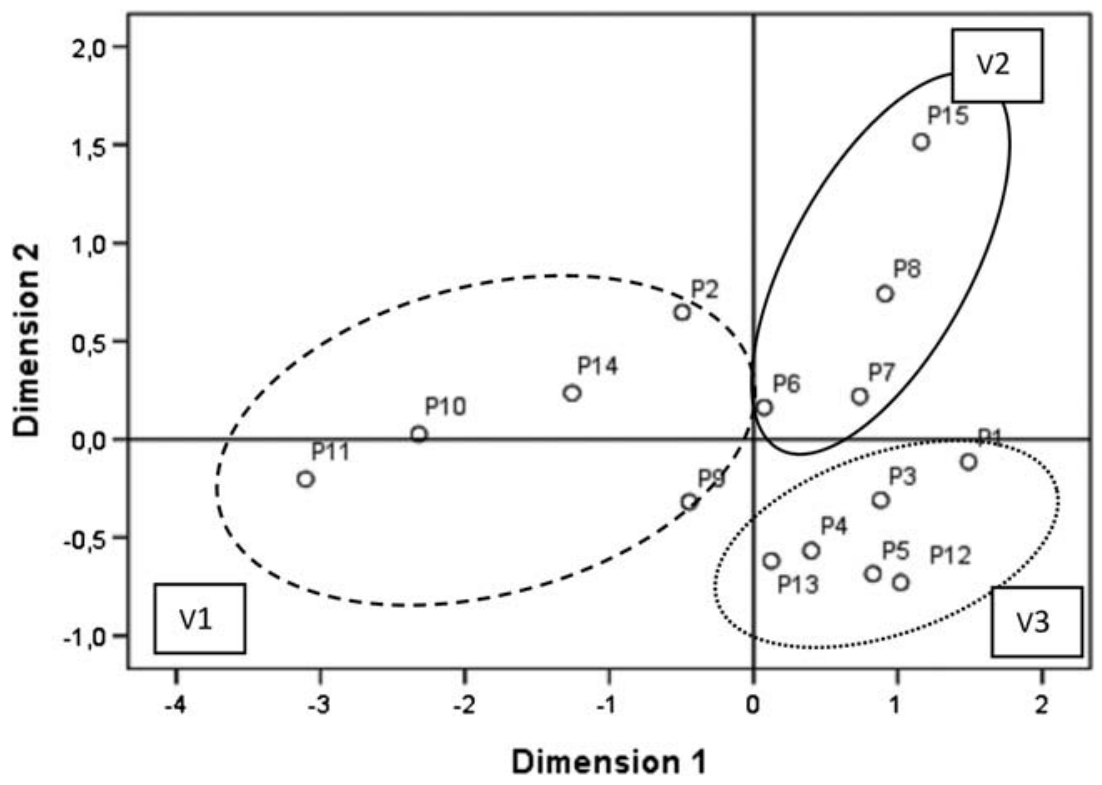

Figure. 1. Projection of the species frequencies of the 15 plots in the system axis 1 and 2 after multidimensional scaling. Figure. 1. Projection des fréquences des espèces dans les quinze placeaux dans un système d'axes bidimensionnel après hiérarchisation multidimensionnelle.

$P i=$ plot $i ; \mathrm{V} 1=$ vegetation type $1 ; \mathrm{V} 2=$ vegetation type $2 ; \mathrm{V} 3=$ vegetation type 3. 
importance of a plant species in the vegetation type. Cluster analysis was performed using SAS software to group the species according to their IVI values in the different identified vegetation types. Principal components analysis was also applied to the IVI data to describe the vegetation types. Projection of the group of species according to their $I V I$ values in the axis system defined by the principal components helped in analysing possible species shifts between vegetation types.

For the whole reserve and for each identified vegetation type, the stem diameter structure was separately established by grouping all the inventoried trees into $10-\mathrm{cm}$ dbh classes. The tree densities were assessed per diameter class and the observed diameter structures were adjusted to the three-parameter Weibull distribution (Johnson and Kotz 1970). Its density function $f$ is expressed for a tree-diameter $x$ as follows:

$$
f(x)=\frac{c}{b}\left(\frac{x-a}{b}\right)^{c-1} \exp \left[-\left(\frac{x-a}{b}\right)^{c}\right]
$$

where $x$ is the tree diameter, $a$ is the location parameter and equal to $10 \mathrm{~cm}$ for the diameter structure, $b$ is the scale parameter linked to the central value of diameters, and $c$ is the shape parameter of the structure.

Diameters of trees were used to estimate the parameters $b$ and $c$ of $\mathrm{Eq}$ (6) based on the maximum likelihood method (Johnson and Kotz 1970). The loglinear analysis (Caswell 2001) was performed in SAS

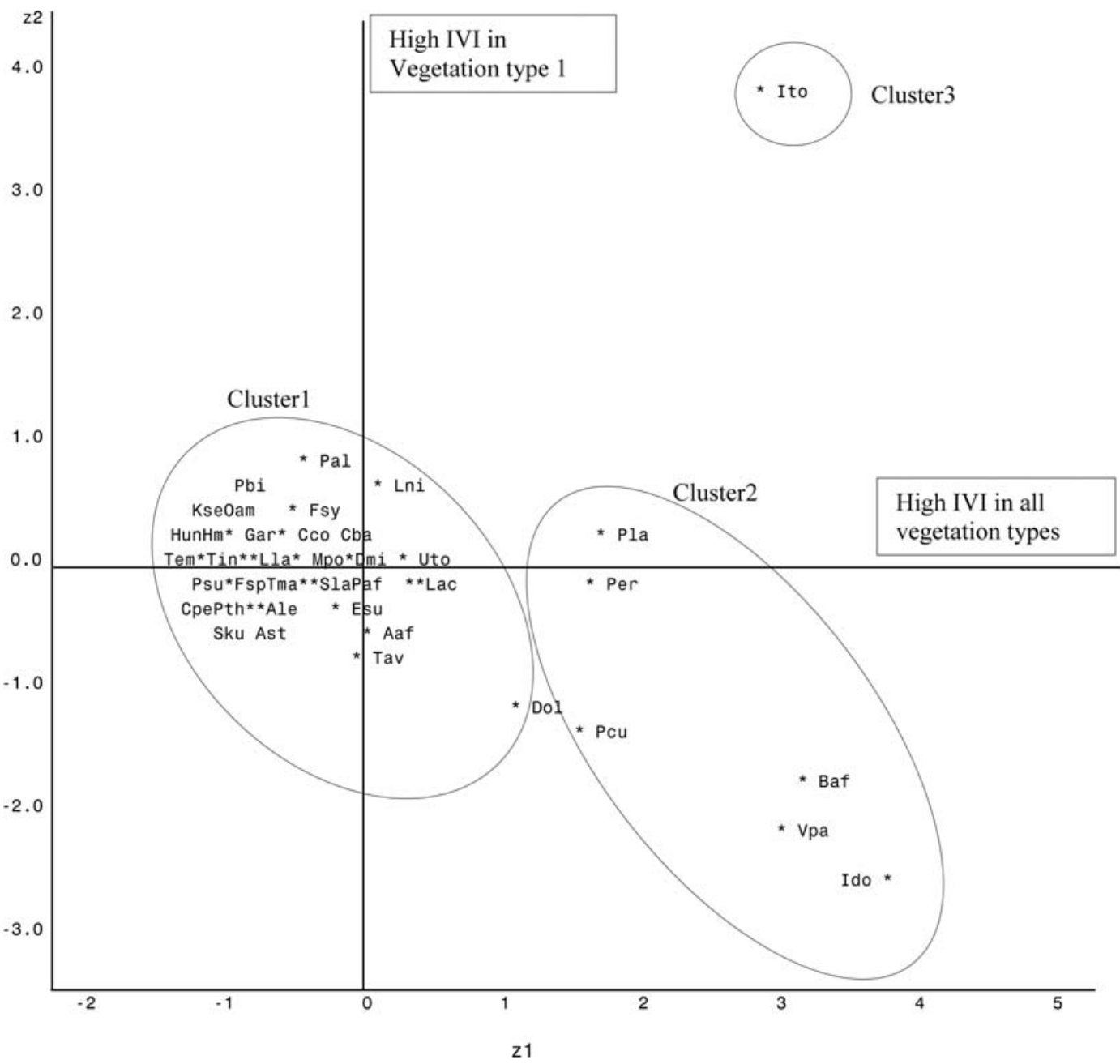

Figure. 2. Projection of the three groups of species according to $I V I$ values onto a principal components analysis system's axes. Figure. 2. Projections des trois groupes d'espèces en fonction des valeurs de l'IVI dans un système d'axes ACP.

$\mathrm{Aaf}=$ Afzelia africana $;$ Ale $=$ Anogeissus leiocarpa $;$ Ast $=$ Aganope stuhlmannii $; \mathrm{Baf}=$ Burkea africana $;$ Cba $=$ Cussonia barteri $;$ $\mathrm{Cco}=$ Combretum collinum $; \mathrm{Cpe}=$ Ceiba pentandra $; \mathrm{Dmi}=$ Detarium microcarpum $;$ Dol $=$ Daniellia oliveri $;$ Esu $=$ Entada sudanica; Fsp = Ficus sp; Fsy = Ficus sycomorus; Gar = Gmelina arborea; Hmo = Hexalobus monopetalus; Hun = Hannoa undulata $;$ Ido $=$ Isoberlinia doka $;$ Ito = Isoberlinia tomentosa $;$ Kse $=$ Khaya senegalensis; Lac $=$ Lannea acida $;$ Lla $=$ Lophira lanceolata $;$ Lni $=$ Lannea nigritana $;$ Mpo = Maranthes polyandra $;$ Oam = Opilia amentacea $;$ Paf $=$ Prosopis africana $;$ Pal $=$ Pouteria alnifolia $; \mathrm{Pbi}=$ Parkia biglobosa $; \mathrm{Pcu}=$ Parinari curatellifolia $;$ Per $=$ Pterocarpus erinaceus $;$ Pla $=$ Pericopsis laxiflora; $\mathrm{Psu}=$ Pteleopsis suberosa $; \mathrm{Pth}=$ Piliostigma thonningii; $\mathrm{Sku}=$ Stereospermum kunthianum; $\mathrm{Sla}=$ Sarcocephalus latifolius; Tav $=$ Terminalia avicennioides; Tem = Trichilia emetica; Tin = Tamarindus indica; Tma = Terminalia macroptera; Uto = Uapaca togoensis; Vpa = Vitellaria paradoxa . 
(SAS Inc. 2003) to test the adequacy of the observed structure to the Weibull distribution.

\section{Results}

\section{Vegetation types}

The characterization of the vegetation leads to the differentiation of three vegetation types V1, V2 and V3. The final value of the stress (0.112) is low. The geometrical representation in the two dimensions is based on the distance between the plots. The projection of species frequencies in the 15 plots after multidimensional scaling is shown in Figure 1. The first dimension represents the species richness gradient of the forest reserve: it discriminates a low species richness vegetation type (V1) from rich ones (V2 and V3). Axis 2 discriminates a vegetation type with high tree density (V2), from another one with low tree density (V3).

Vegetation type 1 (V1) was found in five plots and is characterized by species such as Cassia sieberiana, Strychnos innocua, Isoberlinia tomentosa, Pericopsis laxiflora, Isoberlinia doka, Burkea africana, Lannea nigritana and Vitellaria paradoxa. According to species tree densities, the most represented species of this vegetation type are Cassia sieberiana and Strychnos innocua.

Vegetation type 2 (V2) was found in four plots. The most represented species are Burkea africana, Isoberlinia doka, Pericopsis laxiflora, Parinari curatellifolia, Vitellaria paradoxa and Uapaca togoensis. It differs from the other vegetation types by the presence of species such as Dichrostachys cinerea and Sterculia setigera.

Vegetation type V3 is composed of six plots. The most represented species of this vegetation type are
Vitellaria paradoxa, Burkea africana, Parinari curatellifolia, Daniellia oliveri, Pericopsis laxiflora, Isoberlinia doka. Species exclusive to this vegetation type are Gymnosporia senegalensis, Monotes kerstingii and Swartzia madagascariensis.

Results from cluster analysis on species IVI show three clusters with $92.4 \%$ of the information represented. The projection of the three clusters in the axes system, obtained from the principal components analysis of the IVI values, is shown in Figure 2. The first axis is positively correlated with the species $I V I$ of all three vegetation types and represents the high $I V I$ value for all three vegetation types. The second axis is positively correlated with the species $I V I$ of vegetation type 1 and indicates a high $I V I$ in this vegetation type. Projection of the three clusters (Figure 2) reveals that cluster 3 is constituted of only Isoberlinia tomentosa, the most represented species in all three vegetation types. Species of cluster 2 (Isoberlinia doka, Burkea africana, Pericopsis laxiflora, Vitellaria paradoxa, Parinari curatellifolia and Pterocarpus erinaceus) have a low IVI in all the vegetation types, whereas cluster 1 comprises all other species with intermediate IVI in the three vegetation types.

The computation of IVI for each vegetation type separately shows that vegetation type 1 is dominated by Isoberlinia tomentosa $(I V I=0.788)$, vegetation type 2 by Isoberlinia doka $(I V I=0.501)$ and Burkea africana $(I V I=0.318)$, whereas vegetation type 3 is dominated by Vitellaria paradoxa $(I V I=0.346)$, Isoberlinia doka $(I V I=0.274)$ and Burkea africana $(I V I=0.231)$.

Table 1 shows structural parameters of the whole woodland and individual vegetation types. It indicates little variation in species richness from one vegetation type to another, although this value was relatively high for the overall woodland (57 species). Shannon's

Table 1. Structural parameters of the vegetation types and the whole woodland: mean $(\mathrm{m})$, coefficient of variation (cv, in\%) and probability values $(p)$ of analysis of variance.

Tableau 1. Paramètres structuraux par type de végétation et de l'ensemble de la forêt claire: moyenne $(\mathrm{m})$, coefficient de variation (cv, en\%) et valeurs des probabilités (p) de l'analyse de variance.

\begin{tabular}{|c|c|c|c|c|c|c|c|c|c|}
\hline \multirow[b]{2}{*}{ Parameters } & \multicolumn{2}{|c|}{$\begin{array}{c}\text { Vegetation } \\
\text { type } 1(n=5)\end{array}$} & \multicolumn{2}{|c|}{$\begin{array}{c}\text { Vegetation } \\
\text { type } 2(n=4)\end{array}$} & \multicolumn{2}{|c|}{$\begin{array}{c}\text { Vegetation } \\
\text { type } 3(n=6)\end{array}$} & \multirow[b]{2}{*}{$p$} & \multicolumn{2}{|c|}{ Whole stand } \\
\hline & $\mathrm{m}$ & $\mathrm{cv}$ & $\mathrm{m}$ & $\mathrm{cv}$ & $\mathrm{m}$ & $\mathrm{cv}$ & & $\mathrm{m}$ & $\mathrm{cv}$ \\
\hline $\begin{array}{l}\text { Density } \\
(N, \text { trees/ha) }\end{array}$ & 328.00 & 11.70 & 380.00 & 19.880 & 276.80 & 36.60 & 0.17 & 321.40 & 26.30 \\
\hline $\begin{array}{l}\text { Diameter } \\
\left(D_{g}, \mathrm{~cm}\right)\end{array}$ & 21.20 & 6.50 & 21.20 & 7.890 & 20.10 & 8.50 & 0.46 & 20.80 & 7.60 \\
\hline $\begin{array}{l}\text { Basal area } \\
\left(G, \mathrm{~m}^{2} / \mathrm{ha}\right)\end{array}$ & 11.60 & 9.50 & 13.40 & 21.640 & 8.60 & 23.80 & 0.01 & 10.80 & 25.90 \\
\hline $\begin{array}{l}\text { Species richness } \\
(S \text {, species) }\end{array}$ & 45.00 & - & 50.00 & - & 50.00 & - & - & 57.00 & - \\
\hline $\begin{array}{l}\text { Shannon's } \\
\text { diversity ( } H, \text { bits })\end{array}$ & 3.90 & - & 4.10 & - & 4.50 & - & - & 4.40 & - \\
\hline $\begin{array}{l}\text { Pielou's evenness } \\
\text { Eq }\end{array}$ & 0.71 & - & 0.73 & - & 0.79 & - & - & 0.76 & - \\
\hline
\end{tabular}

$n$ is the total number of plots in each vegetation type. 


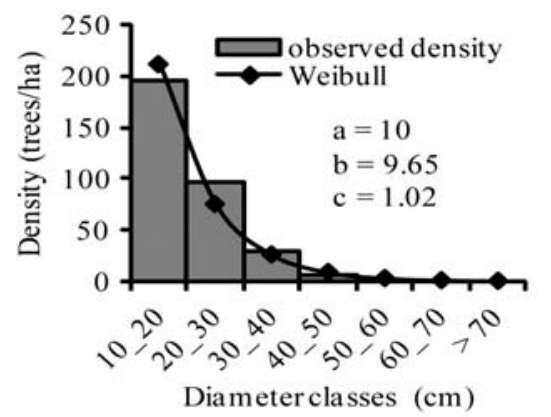

Vegetation type 1

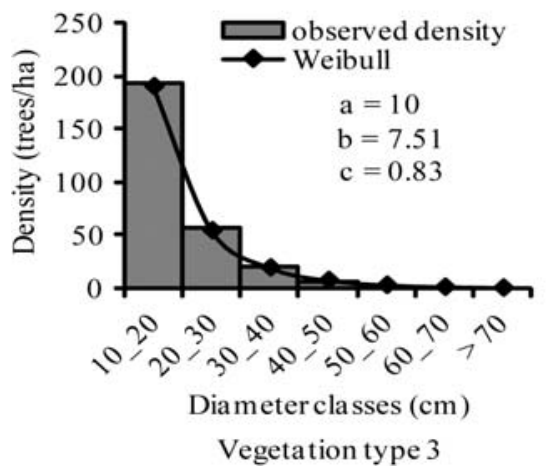

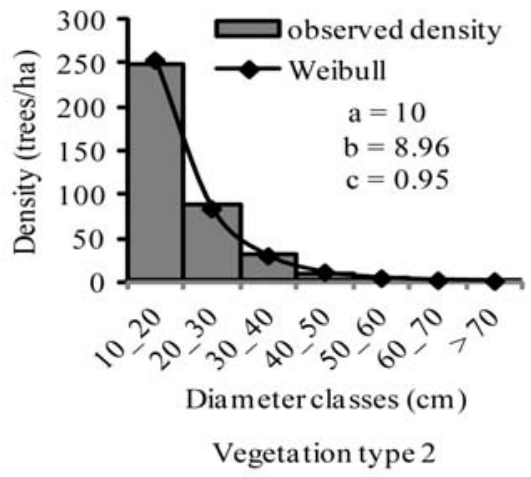

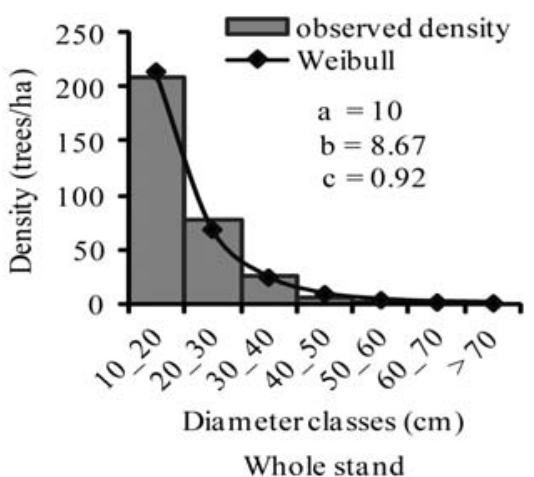

Figure. 3. Stem diameter structure of the identified vegetation types and the whole stand.

Figure. 3. Structure diamétrique des types de végétations identifiées et du peuplement global.

diversity index shows its highest value for vegetation type 3, whereas Pielou's evenness shows similar values whatever the vegetation type.

Only basal areas were found to be significantly different across the three vegetation types (ANOVA; $p=$ $0.01)$.

The mean basal area is $10.83 \mathrm{~m}^{2} /$ ha and its highest value is recorded in vegetation type 2 . The average tree density is 321.4 trees/ha. The highest value is obtained in vegetation type 2 and the smallest one in vegetation type 3 . However, vegetation type 3 is more diversified ( $S$ $=50$ and $\mathrm{Eq}=0.79)$ than the others. The mean tree diameter is $20.76 \mathrm{~cm}$ and the highest values are observed for vegetation types 1 and 2 .

\section{Stem diameter structure}

The stem diameter structure of the three vegetation types and the whole woodland (Figure 3) shows an inverse " $J$ " shape, with values of the shape parameter ( $c$ of the Weibull distribution) very close to 1 , characterizing natural multispecies populations. The log-linear analysis indicates a good adjustment to the Weibull distribution $(p>0.05)$. Trees of $10-40 \mathrm{~cm}$ dbh are the most represented and the most abundant species in these diameter classes are Isoberlinia tomentosa and Pericopsis laxiflora for plant vegetation type V1; Burkea africana and Pericopsis laxiflora for vegetation type V2; and Vitellaria paradoxa, Burkea africana and Parinari curatellifolia for vegetation type V3. Moreover, very few trees have a dbh $>50 \mathrm{~cm}$.

\section{Discussion}

This paper provides information on woodlands in the Sudano-Guinean transition zone of Benin. Until now, relatively little information was available on floristic and dendrometric characteristics of woodlands in this region.

As far as floristic composition of the vegetation types is concerned, the study reveals that, the three vegetation types contain almost the same tree species. However, the IVI values show marked differences in the dominant species of the different vegetation types. This confirms hypothesis (i), which assumed that the studied forest shelters different vegetation types. The differences in species importance across vegetation types may suggest local differences of ecological conditions (e.g. soil properties and topographical characteristics) as reported elsewhere (Ganglo 2005; Ganglo and De Foucault 2006).

Tree density significantly varies among vegetation types. The highest density is observed for vegetation type 2 (380 trees/ha) whereas vegetation type 3 shows the lowest density (277 trees/ha). Mean density for the whole stand is estimated at 321.4 trees/ha. The relatively low value observed for vegetation type 3 may be explained by its overexploitation through tree logging (personal observation).

Mean dbh value for the whole stand was estimated at $20.8 \mathrm{~cm}$. A slightly larger value was reported elsewhere $(24.4 \mathrm{~cm})$ for woodlands in drier areas of the Sudano- 
Guinean transition zone (Glèlè Kakaï and Sinsin 2009). This difference may be linked to either (i) differences in density (321.4 trees/ha versus 202.8 trees/ha), which may result in higher competition between trees in the Belléfoungou forest reserve, (ii) differences in dominant life stages, or (iii) higher logging pressure on large stems, which may have artificially biased the life stage ratio in favour of young stems.

The mean basal area significantly varies between 8.55 and $13.36 \mathrm{~m}^{2} /$ ha for identified vegetation types. This corresponds with observed differences between vegetation types as far as the tree-density is concerned.

Diameter size class distributions are often reported in the literature to be of great interest for forest management because they are used as indicators of stand structure and dynamics (Van Laar and Akça 2007). In this study, all diameter size class distributions fitted the Weibull distribution and showed an inverse " $J$ "-shaped curve. These results disagree with hypothesis (ii) and would suggest young stems (especially those ranging from 10 to $20 \mathrm{~cm}$ ) to be relatively more abundant than adults stems, irrespective of vegetation types and for the whole stand. Observed structures may also suggest good ecological conditions for transition from sapling stage to young trees (Assogbadjo et al. 2010). Similar findings were previously reported for Isoberlinia-dominated vegetations in a drier part of the Sudano-Guinean transition zone (Glèlè Kakaï and Sinsin 2009). However, large stems, i.e. trees with $\mathrm{dbh}>50 \mathrm{~cm}$, were found to be scarce. This may be caused by the illegal tree logging that the forest reserve is facing, as mentioned above. Moreover, foliage pruning for traditional medicine, pasture and feeding purposes (field observation) could have also negatively affected the growth rate of the trees (Bayer and Waters-Bayer 1999). If not controlled, these anthropogenic pressures may in the long term critically decrease the number of mature trees and recruitment.

Although our results would suggest the study stand and identified vegetation types to be extending (i.e. many young stems), this may not be the case for individual species facing logging. A better understanding of the stem diameter distribution determinism needs consideration of other factors, e.g. environmental conditions, soil, topography, competition among species, (Sinsin et al. 2004). Furthermore, the shape parameter of the three-parameter Weibull distribution is not necessarily a good predictor of stand dynamics (see Feeley et al. 2007; Fandohan et al. 2011). Hence, interpreting outputs requires caution.

The presented floristic characteristics differentiate three vegetation types in the Belléfoungou Forest Reserve. The whole woodland hosts 57 woody species representing around $2 \%$ of the national flora. Adomou et al. (2010) suggest that priority sites for biodiversity conservation in Benin should host at least $20 \%$ of the national flora. This would suggest that the Belléfoungou forest reserve is not of prime importance as far as biodiversity conservation is concerned at national level. However, only trees were considered in this study, and the exact percentage of the national flora represented within the reserve might be much higher than $2 \%$, if grasses and mosses were included. Furthermore, given its location in a wet part of the Sudano-Guinean transition zone that resulted from past floristic connections with the Upper Guinean forest block (Adomou et al. 2010), it may offer particular ecological conditions that deserve further scientific interest and conservation actions. Besides, local people may also benefit from the conservation and sustainable use (e.g. tourism) of this reserve.

Finally, in the light of results from this study and field observations, we would suggest regulation of access to Belléfoungou forest reserve to reduce the pressures it has been facing (e.g. logging and overharvesting of nontimber products). In that respect, actions for effective conservation would include: (i) setting and implementing a management plan with actual participation of all stakeholders, and (ii) reinforcement of supervision by rangers.

\section{Acknowledgments}

We are very grateful to E.E. AGO who financially supported this study. B. Fandohan also received a post doctoral research grant from the Chinese Academy of Sciences (grant No 2012Y1ZA0009) which provided him with good scientific environment to complete and correct the manuscript. We also thank Aida Cuni Sanchez and the reviewers for their comments on a previous version of the manuscript.

\section{References}

Adomou, A.C., B. Sinsin, A.A. Akoégninou, and J. van der Maesen. 2010. Plant species and ecosystems with high conservation priority in Benin. In Systematics and Conservation of African Plants, ed. X. van der Burgt, J. van der Maesen, and J.-M. Onana, 429-44. Kew: Royal Botanic Gardens.

Adomou, C.A. 2005. Vegetation Patterns and environmental gradients in Benin. Implications for biogeography and conservation. $\mathrm{PhD}$ diss., Wageningen University, Wageningen.

Assogbadjo, A.E., R.L. GlèlèKakaï, B. Sinsin, and P. Dieter. 2010. Structure of Anogeissus leiocarpa Guill., Perr. natural stands in relation to anthropogenic pressure within Wari-Maro Forest Reserve in Benin. African Journal of Ecology 48, no. 3: 644-653.

Bayer, W., and A. Waters-Bayer. 1999. La Gestion des Fourrages. Wageningen: CTA.

Bellefontaine, R., A. Gaston, and Y. Petrucci. 2000. Management of natural forest of dry tropical zones. Conservation Guide, no.32. Rome: Food and Agricultural Organization (FAO).

Braun-Blanquet, J. 1972. Plant sociology: the study of plant communities (Facsimile of the edition of 1932, translated by Fuller, G.D., and H.S. Conard). New York: Hafner Publishing Company.

Caswell, H. 2001. Matrix Population Models: Construction Analysis and Interpretation. 2nd ed. Sunderland (MA): Sinauer Associates.

Curtis, J.T., and R.P. Macintosh. 1951. An upland forest continuum in the prairie forest border region of Wisconsin. Ecology 32: 476-496. 
du Toit, J.T., B.H. Walker, and B.M. Campbell. 2004. Conserving tropical nature: current challenges for ecologists. Trends in Ecology and Evolution 19, no. 1: $12-17$.

Fandohan, B., A.E. Assogbadjo, R.L. Glèlè Kakaï, and B. Sinsin. 2011. Effectiveness of a protected areas network in the conservation of Tamarindus indica (LeguminoseaCaesalpinioideae) in Benin. African. Journal of. Ecology 49: $40-50$

Feeley, J.K., S.J. Davies, M.D. Nur Supardi Noor, S.J. Davies, A.R. Kassim, and S. Tan. 2007. Do current stem size distributions predict future population changes? An empirical test of intraspecific patterns in tropical trees at two spatial scales Journal of Tropical Ecology 23: 191-198.

Ganglo, J.C., and B. De Foucault. 2006. Plant communities, forest site identification and classification in Toffo reserve, South-Benin. Bois et Forêts des Tropiques 288, no. 2: 25-38.

Ganglo, J.C. 2005. Groupements de sous-bois, identification et caractérisation des stations forestières: cas d'un bois au Bénin. Bois et Forêts des Tropiques 285, no. 3: 35-46.

Glèlè Kakaï, R., and B. Sinsin. 2009. Structural description of two Isoberlinia dominated vegetation types in the WariMaro Forest Reserve (Benin). South African Journal of Botany 75: 43-51.

Hardy, O.J., and B. Sonké. 2004. Spatial pattern analysis of tree species distribution in a tropical rain forest of Cameroon: assessing the role of limited dispersal and niche differentiation. Forest Ecology and Management 197: 191-202.

Hékpazo, P. 1996. Recueil des textes de classement et de déclassement des forêts, des périmètres de reboisement et des réserves en République du Bénin. Cotonou: Direction Generale des Forêts et des Ressources Naturelles

Hubbell, S.P. 2001. A unified neutral theory of biodiversity and biogeography. Princeton (NJ): Princeton University Press.

Huston, M.A. 1994. Biological diversity: the coexistence of species on changing landscapes. Cambridge: Cambridge University Press.

Johnson, N.L., and S. Kotz. 1970. Distributions in statistics: 399 continuous univariate distributions. New York: John Wiley \& Sons.

Kent, M., and P. Coker. 1992. Vegetation description and analysis. A practical approach. Chichester: John Wiley \& Sons. Chichester.
Lebrun, J-P., and A.L. Stork. 1991-1997. Enumération des plantes à fleurs d'Afrique tropicale. 4 volumes. Geneva: Conservatoire et Jardin Botanique de la ville de Genève.

Myers, N., R.A. Mittermeier, C.G. Mittermeier, G.A.B. Da Fonseca, and J. Kent. 2000. Biodiversity hotspots for conservation priorities. Nature 403: 853-858.

Natta, A.K. 2003. Ecological assessment of riparian forest in Benin: phytodiversity, phytosociology and spatial distribution of tree species. $\mathrm{PhD}$ diss., Wageningen, Wageningen University.

Pennie, J. 2008. Carbon and Communities in Tropical Woodlands: an international interdisciplinary conference. http://www.geos.ed.ac.uk/abs/MiomboConference (Accessed June 30, 2011).

Russell-Smith, J. 1991. Classification, species richness, and environmental relations of monsoon rain forests in northern Australia. Journal of Vegetation Science 2: 259-278.

SAS Institute Inc. 2003. SAS OnlineDoc ${ }^{\circledR}$ Version 9.1. Cary (NC): SAS Institute Inc.

Sinsin, B., O. Eyog Matig, A.E. Assogbadjo, O.G. Gaoué, and T. Sinadouwirou. 2004. Dendrometric characteristics as indicators of pressure of Afzelia africana Sm. trees dynamics in different climatic zones of Benin. Biodiversity and Conservation 13: 1555-1570.

Sokpon, N., S.H. Biaou, C. Ouinsavi, and O. Hunhyet. 2006. Bases techniques pour une gestion durable des forêts claires du Nord-Bénin: rotation, diamètre minimal d'exploitabilité et régénération. Bois et Forêts des Tropiques 287, no. 1: 45-57.

The Nature Conservancy. 2003. The five-S framework for site conservation: a practitioner's handbook for site conservation planning and measuring conservation success. 3rd ed. Arlington (VA), : Nature Conservancy.

Van Laar, A., and A. Akça. 2007. Forest mensuration. Dordrecht: Springer, 383 p.

White, F. 1983. The vegetation map of Africa south of the Sahara. 2nd ed Paris: UNESCO.

Whitmore, T.C. 1990. An introduction to tropical rain forest. Oxford: Clarendon Press.

World Bank. 1998. World development indicators 1998: International Bank for Reconstruction and Development. Washington, D.C: World Bank.

World Bank. 2001. Sustainable woodfuel supplies from the dry tropical woodlands, ESMAP. Washington, D.C: World Bank. 